\title{
Oleh Krytskyi
}

National Medical University named after O.O. Bohomolets (Kyiv, Ukraine)

https://orcid.org/oooo-ooo3-2684-2997

e-mail:gelovk@gmail.com

\section{THE ROLE OF SPIRITUAL VALUES IN THE PROFESSIONAL ACTIVITY OF A MEDICAL WORKER}

\begin{abstract}
The article presents a philosophical analysis of the role of spiritual values in the professional activity of a medical worker. It is noted that in the modern conditions of civilizational development there are new challenges that actualize the problem of the value dimension of human activity. This is primarily due to the coronavirus pandemic (COVID-19), which spread almost worldwide during the year. As a result of the intense spread of coronavirus disease around the globe, medical workers today find themselves in extremely difficult or even extreme working conditions. In addition, in some countries this category of workers does not have adequate financial and social guarantees. As a result, there is a problem of value measurement of professional activity of medical workers. The essence of this problem is the contradictory relationship between the state (government), society and medical workers, where the effectiveness of the latter is considered on the basis of its compliance with moral, legal and other social requirements, without taking into account the needs, interests and desires of health workers.

It is stated that the formation of a professional medical worker should necessarily be aimed at the development of a spiritually rich, value-oriented personality, which is conscientious, strong-willed, responsible, competent, persistent, purposeful; uses trust, duty, self-improvement, rational use of its own essential forces, living space, constantly improves the forms and types of activities, cultivates a careful attitude to all forms of life. society.

Key words: values, value orientations, activity, medical worker,
\end{abstract}




\section{Крицький Олег Васильович}

Національний медичний університет імені О. О. Богомольця (м. Киӥв, Украӥна)

https://orcid.org/oooo-ooo3-2684-2997

e-mail:gelovk@gmail.com

\section{РОЛЬ ДУХОВНИХ ЦІННОСТЕЙ У ПРОФЕСІЙНІЙ ДІЯЛЬНОСТІ МЕДИЧНОГО ПРАЦІВНИКА}

\section{Резюме}

У статті здійснено філософський аналіз ролі духовних цінностей у професійній діяльності медичного працівника. Зазначено, що в сучасних умовах цивілізаційного розвитку існують нові виклики, які актуалізують проблему ціннісного виміру діяльності людини. Це пов'язано, насамперед, з пандемією коронавірусу (COVID-19), яка протягом року поширилася практично на увесь світ. В результаті інтенсивного поширення коронавірусної хвороби земною кулею працівники медичної сфери сьогодні опинилися в надзвичайно складних, чи навіть екстремальних умовах праці. Крім цього, у ряді країн належних фінансових і соціальних гарантій дана категорія працівників не має. Як наслідок, виникає проблема ціннісного виміру професійної діяльності медпрацівників. Суть цієї проблеми полягає у суперечливих взаємовідносинах між державою (владою), суспільством і працівниками медичної сфери, де ефективність діяльності останніх розглядається, виходячи з їі відповідності моральним, правовим нормам та іншим соціальним вимогам, не враховуючи належним чином потреби, інтереси i бажання самих медпрацівників.

Обгрунтовано, що в будь-якому суспільстві культура впливає на процес формування системи цінностей, а з іншого боку система цінностей того чи іншого суспільства складає основу культури соціуму. Тому це ще раз вказує на доцільність застосування аксіологічного підходу при дослідженні професійної діяльності медпрацівників. Адже у житті суспільства цінності виступають важливими соціально-значимими орієнтирами діяльності суб’єктів, одним із факторів розгортання суспільно-історичного розвитку. Саме через цінності людина задовольняє свої потреби, інтереси і бажання. 
3'ясовано, що для кожного історичного періоду характерною 6 наявність певного специфічного набору та ієрархї̈ цінностей, система яких виступає як авторитетний регулятор відносин у суспільстві. У цій системі завжди зафіксовані поняття і критерії, визнані конкретним суспільством, у зв'язку з чим вони стають основою для більш конкретних і спеціалізованих систем нормативного контролю, відповідних громадянських інститутів та цілеспрямованих дій людей. Лише засвоєння цієї системи цінностей окремою особою може створити необхідну основу для підтримання певного усталеного порядку у суспільстві. Не дивлячись на те, що сучасне суспільство характеризується поширенням феномену споживання, намагання відновити роль і значення духовних цінностей в процесі діяльності індивіда сьогодні не позбавлені смислу. В контексті сучасності показник успішності має включати духовні якості людини, гуманістичні засади формування ціннісно-орієнтованої особистості. Доведено, що на сьогодні у діяльності медпрацівників визначальними є такі духовні цінності, як: віра, надія, любов, довіра, совість, воля, відповідальність, обов'язок, компетентність, толерантність, цілеспрямованість тощо.

Констатовано, що формування професійного медпрацівника з необхідністю має бути спрямоване розвиток духовно-багатої, ціннісноорієнтованої особистості, яка є совісною, вольовою, відповідальною, компетентною, наполегливою, цілеспрямованою; послуговується довірою, обов'язком, самовдосконалюється, раціонально використовує власні сутнісні сили, життєвий простір, постійно вдосконалює форми та види діяльності, виховує бережливе ставлення до всіх форм живого.

Ключові слова: цінності, ціннісні орієнтації, діяльність, медпрацівник, суспільство.

\section{Bcmyn}

Сучасний етап цивілізаційного розвитку формує нові вимоги до суспільства в цілому і до суб’єктів різних сфер діяльності зокрема. Не виключенням $\epsilon$ медична сфера, працівники якої сьогодні практично у всьому світі опинилися в надзвичайно складних, чи навіть екстремальних умовах праці. Це пов’язано з пандемією коронавірусу (COVID-19), яка протягом року поширилася практично на увесь світ. За офіційними даними наприкінці 2020 року у світі зафіксовано понад 47 мільйонів випадків захворювання у майже у всіх країнах світу, близько 1 мільйона людей померло. До таких масштабів і темпів поширення захворювання системи охорони здоров'я більшості держав виявилися не готові. 3 цього приводу глава ВООЗ Тедрос Гебрейєсус окреслив чотири сценарії поширення коронавірусної хвороби у світі. Перший сценарій реалізувався в країнах, які були попереджені і обізнані про спалах хвороби - в результаті їм вдалося уникнути великих спалахів (деякі країни Південно-Східної Азії, Карибського басейну, Африки 
та Тихоокеанського регіону), другий сценарій спостерігався в багатьох країнах Європи (масштабні спалахи захворювання, проте їх вдалося взяти під контроль завдяки сильному керівництву), третій сценарій розвертався в країнах, яким вдалося подолати перший пік спалаху хвороби, проте вони послабили обмеження і тепер змушені боротися з новою хвилею захворювання, четвертий сценарій - фаза інтенсивної передачі інфекції (Америка, Південна Азія і кілька країн Африки).

У кожному із цих сценаріїв надзвичайно велике навантаження припадає саме на медпрацівників, котрі у деяких країнах (наприклад, Україна) у фінансовому плані є однією із незахищених категорій працівників. Вказані виклики по новому актуалізують проблему ціннісного виміру професійної діяльності медпрацівників. Суть цієї проблеми полягає у суперечливих взаємовідносинах між державою (владою), суспільством і працівниками медичної сфери, де ефективність діяльності останніх розглядається, виходячи з її відповідності моральним, правовим нормам та іншим соціальним вимогам, не враховуючи належним чином потреби, інтереси і бажання самих медпрацівників. За основу береться дотримання соціальних інтересів, а основним критерієм оцінки виступає міра виконання медпрацівниками свого професійного і соціального призначення, рівень забезпечення здоров’я громадян. Саме тому метою даної статті є філософський аналіз засадничих індивідуально моральних і соціальних цінностей професійної діяльності медпрацівників.

Як відомо, науковою формою ціннісного дослідження людської діяльності постає аксіологія, під якою розуміється система знань про цінності й ціннісні орієнтації суб'єктів як смислотворчі засади їх життєдіяльності, що скеровують їх думки, вчинки та дії. Дослідженням цінностей займалися ще мислителі давніх часів, але аксіологія як самостійна галузь філософського знання формується лише в кінці XIX ст. - на поч. XX ст. в роботах неокантіанців (В. Віндельбанд, Г. Ріккерт) та набуває розвитку в працях таких мислителів як: К. О. Апель, Ф. Брентано, Ю. Габермас, А. Макінтайєр, М. Фуко, М. Шелер та ін. ).

У кінці XX ст. на поч. XXI ст. філософські питання цінностей досліджували такі вчені, як: І. Бичко, В. Василенко, С. Горбунова, П. Гуревич, М. Каган, Д. Керимов, С. Кримський, В. Кузнєцов, Д. Леонтьєв, М. Підлісний М. Попович, О. Ручка, В. Табачковський, В. Шинкарук та інші.

Окремі питання відношення ціннісного змісту діяльності лікарів розглядаються у працях таких сучасних українських вчених, як: М. Ісламова, Л. Качала, Р. Погоріляк, І. Рогач, Т. Скрябіна та інші.

\section{Результати дослідження}

Дослідження будь-якого суспільства демонструє, що культура впливає на процес формування системи цінностей, а 3 іншого боку система 
цінностей того чи іншого суспільства складає основу культури соціуму. Тому це ще раз вказує на доцільність застосування аксіологічного підходу при дослідженні професійної діяльності медпрацівників. Адже у житті суспільства цінності виступають важливими, соціально-значимими орієнтирами діяльності суб’єктів, одним із факторів розгортання суспільноісторичного розвитку. Саме через цінності людина задовольняє свої потреби, інтереси і бажання.

Філософія визначає цінності як поняття, що «позначають належне та бажане, на відміну від реального, дійсного» [8, с.707]. При цьому потрібно заначити, що філософські узагальнення щодо цінностей і їх ролі в життєдіяльності людини і суспільства формуються ще в межах античної традиції розуміння відношення людини до світу через призму дихотомії знання та моралі. Вагомий доробок у теорії цінностей належить I. Канту, який вважав, що моральні норми (імператив) $є$ формальним законом, який не змушує, що людина повинна хотіти, а тільки визначає як вона повинна хотіти, оскільки сутність добра - це формальна якість волі. Розробляючи регулятивні принципи практичного розуму, філософ створює специфічну галузь філософського знання - теорію цінностей, відповідно до якої вищі цінності буття мають не онтологічні, а регулятивні підстави до існування. Кантівську традицію розуміння цінностей як регулятивів буття людини продовжили В. Віндельбанд, Г. Ріккерт, які людську історію розуміли як процес усвідомлення та втілення цінностей, серед яких визначальне місце належить саме духовним цінностіям, що, на думку мислителів, не існують у вигляді самостійних предметів, а пізнаються суб'єктивно, як принципи, що підлягають обов'язковому дотриманню.

Інші мислителі, наприклад, Н. Смелзер, у зміст поняття цінності вкладає «розділені в суспільстві переконання відносно цілей, до яких люди повинні прагнути та основних засобів їх досягнення (термінальні, інструментальні цінності)» [10, с. 660]. Т. Парсонс визначає цінності як «загальноприйняті уявлення про бажаний тип соціальної системи» $[1$, с.368]. На думку цього вченого, абстрактні нормативні системи перетворюються в реально функціонуючі саме завдяки їх ціннісному змісту. Відбувається свого роду легітимація, виправдання правових, моральних та інших норм через наділення їх ціннісним змістом, включенням у ціннісні відносини. Зазначені визначення передбачають те, що цінності-це ідеальні об'єкти, не існуючі поза фактами людської психіки (поглядами, уявленнями, переконаннями тощо).

Слід зазначити, що всі ці вчення так і не вирішили одвічну філософську дилему чи може людина, у своїй життєдіяльності, керуватися лише власним розумом, чи вона має визнати існування вищих від розуму цінностей, які потрібно сприймати як закон. Більше того, до сьогоднішнього дня у науковій літературі не існує єдиного визначення поняття «цінність». 
У розмаїтті визначень акцент робиться на цінності як специфічній формі прояву відносин між суб'єктом і об’єктом стосовно задоволення потреб та інтересів суб’єкта. 3 цього приводу вітчизняний вчений М. Підлісний зазначає: «Цінність - це не річ, і не явище, узяте саме по собі, безвідносно до людини. Цінність - це речі, звернені до людини. У цьому значенні цінність не є сам предмет, цінність - це предмет у його взаємозв'язку з людиною, з точки зору його значимості для людини» [9, с. 17].

Отже, у широкому розумінні цінностями можуть бути предмети людської діяльності, суспільні відносини і включені в їх коло природні процеси можуть бути об `єктами ціннісного відношення, а також суб’єктивні оцінки, установки й норми, котрі закріплені в суспільній свідомості й існують як способи та критерії, за якими змінюється дійсність і діяльність людини. Відтак, цінності можна визначити як те, на що орієнтується суб Єєт у своїй діяльності, а також те, що є результатом цієї діяльності людини. Для кожного історичного періоду характерною є наявність певного специфічного набору та ієрархії цінностей, система яких виступає як авторитетний регулятор відносин у суспільстві. У цій системі завжди зафіксовані поняття і критерії, визнані конкретним суспільством, у зв'язку з чим вони стають основою для більш конкретних і спеціалізованих систем нормативного контролю, відповідних громадянських інститутів та цілеспрямованих дій людей. Наприклад, для сучасного суспільства, яке науковці позначають концептом «інформаційне суспільство», визначальними є такі цінності, як інформація, знання, незалежність, свобода, креативність тощо. Суспільні відносини, які упорядковані такими регулятивами «зумовлюють необхідність розвитку таких рис та якостей особистості як: професіоналізм (у напрямку використання сучасних технологій); духовність як переважання в людини духовно-моральних, інтелектуальних якостей (цінностей) над матеріальними; соціальна відповідальність як міра відповідності дій соціальних суб'єктів взаємним вимогам, діючим правовим та іншим соціальним нормам і загальним інтересам; здатність до творчої побудови та реалізації власного життєвого проекту на основі культури і загальносоціальних норм тощо» [10, с. 62-63].

У цьому контексті слід зазначити, що ціннісне ставлення, розглянуте з боку суб'єкта, реалізується двояко: як відношення до цінності оцінюваного об'єкта і як його осмислення. Ця двоїстість пояснюється тим, що, поперше, у сприйнятті кожного об’єкта суб'єкт виходить з уже сформованих у нього уявлень, цінностей і оцінок даного об’єкта, виражається у відношенні до цінності, і по-друге, ціннісне ставлення припускає можливість осмислення оцінюваного, тобто розуміння суб'єктом того сенсу, який має для нього даний об’єкт. Кожна особа створює свою ієрархію цінностей, відповідно до якої і будує свою життєдіяльність. Важливим завданням, яке намагається виконати філософія, $\epsilon$ вироблення таких орієнтирів відношення 
та способів взаємодії людини і світу, які б уможливили їх гармонійне подальше співіснування. 3 цього приводу Г. Кісельов зазначає: «Не дивлячись на вражаючі досягнення людського роду в різних галузях, навряд чи доводиться говорити про його помітне моральнісне сходження» [5, с. 3-4].

Подібну точку зору висловлює вітчизняний науковець В. Ільїн, який зауважує, що «у міру розвитку господарської системи, наповнення життя товарами, торгово-економічними послугами, демократизацією суспільного буття, пом'якшенням соціальної напруги, переходом від особистої залежності до залежності лише речової, економічної відбувалися зміни в опозиції матеріального і духовного. Антиматеріальні цінності втратили здатність вносити смисл і смислотворчий порядок у життя людини і суспільства» [4, с. 476 - 477]. У цьому контексті справедливо зазначають українські дослідники Є. Левченюк, Ф. Власенко та Д. Товмаш, «сьогодні у суспільстві пропагуються соматичні та утилітарні категорії, зокрема корисливість, влада, гламур, консюмеризм, нетерпимість, егоїзм, симуляція, зухвалість тощо» [7, с. 167].

Разом $з$ тим, говорити про відсутність цінностей, «бездуховність» не коректно. «Постлюдина духовна такою ж мірою, як і людина епохи Просвітництва. Тільки духовність у неї інша - раціональна, технічна, прагматична, «огрошівлена» [4, с. 498]. Дійсно, аксіологічні горизонти нового гуманізму репрезентовано цінностями конструктивного і продуктивного розвитку індивідів. Тим не менше, намагання відновити роль і значення духовних цінностей в житті індивіда сьогодні не позбавлені смислу. У контексті сучасності показник успішності з необхідністю включає духовні якості людини і засади формування ціннісно-орієнтованої особистості.

Основними духовними цінностями, які є необхідною умовою становлення та розвитку особистості в контексті динаміки сучасних суспільних процесів є: віра, надія, любов, довіра, совість, воля, відповідальність, обов'язок, компетентність, толерантність, цілеспрямованість тощо.

Фундамент духовності складає єдність таких духовно-практичних вимірів людини, як віра, надія, любов. Так, формування життєвої позиції особистості стає можливим за умови пошуку та переживання різних можливостей, створення на їх основі образу майбутнього. I тут саме віра постає тим особливим екзистенційним духовним началом життєдіяльності людини, на основі якої формується ідеал, що, у свою чергу, постає не тільки взірцем, а й метою діяльності людини. Отже, віру можна назвати впевненістю людини в існуванні будь-якого явища, визнання його реальності. Це почуття і усвідомлення людиною певного ідеалу як вищої сутності, до якої вона прагне.

Поняття «філософська віра» у філософський дискурс було введено німецьким мислителем екзистенціалістом К. Ясперсом. На його думку воно означає впевненість людини в існуванні буття, з яким ми щоденно 
взаємодіємо, до якого належимо, але, яке за своєю сутністю, є відмінним від нашого уявлення про нього. На відміну від релігійної, догматичної філософська віра грунтується на переконанні й обгрунтуванні можливості перетворювати невідоме на пізнане.

Не дивлячись на існуючу суперечність розуму, досвіду, віра визначається як духовна цінність, оскільки надихає людину на певне волевиявлення, на дію, що перетворює випадкові обставини на умови самореалізації. Саме тому віра є важливою детермінантою у професійній діяльності медпрацівника, оскільки завдяки їй працівник долає власну обмеженість, робить крок у невідоме майбутнє, стає на шлях саморозвитку. Без неї стомлена життєвими проблемами людина, яка зазнала краху своїх життєвих планів, може зневіритися в собі, в інших, в житті. У зв'язку з цим, важливим завданням для медичного працівника є вміння повернути людині (хворому) віру в одужання, в себе, в ближніх, відчути себе невід’ємною складовою соціального організму.

Поряд з вірою в повсякденній життєдіяльності людини їі впевненість в існуванні іншого, на кого можна розраховувати, хто зможе допомогти спирається на особливий стан чуттєвих переживань і свідомості - надію. Під останньою розуміють почуття і усвідомлення людиною сподівання на позитивні наслідки змін, що відбуваються у світі. Відтак, надія породжує в особистості ентузіазм, впевненість в своїх можливостях змінити світ на краще. Таким чином, надія також відіграє важливу роль у діяльності медпрацівника, оскільки організовує людину на шляху до реалізації визначених мети та цілей через сподівання бажаного й очікуваного на підставі особистісного досвіду, віри і знань.

Як наслідок, в людини формується здатність до почуттєвого виявлення окремих предметів, явищ, суб'єктів як невід’ємної умови свого існування. Усвідомлення людиною когось або чогось як невід'ємної умови свого життя позначається поняттям любові. У філософії любов визначається як «екзистенціал людського буття, який окреслює найглибше відчуття повноти особистісного буття і переживання цілісності у з'єднанні з іншою особистістю та світом» [6, с.348].

У сучасній філософії грунтовний аналіз проблеми любові, як духовної детермінанти життєдіяльності людини, здійснив Е. Фромм. У своїй праці «Мистецтво любити» мислитель виокремив різні прояви любові, зокрема: братерська любов, материнська любов, еротична любов, любов до себе, любов до Бога. Для нашого дослідження особливо цікавим є розуміння філософом сутності братерської любові, яку він визначає як любов рівних, але зазначає, що в житті, навіть маючи рівні права, ми не завжди «рівні» [11, с.119]. Далі автор наводить цікаві роздуми, які, на наш погляд, є важливими для розуміння сутності соціальної роботи, місця й ролі в ній любові. 
Будучи людьми, всі ми потребуємо допомоги - сьогодні я, завтра ти. Безпорадність - тимчасовий стан; природним і постійним $\epsilon$ вміння стояти і ходити на власних ногах. Лише любов до безпорадних, бідних, незнайомих - це початок братерської любові. Адже безпорадний любить свого господаря, тому що від нього залежить його життя; дитина любить своїх батьків, оскільки вони їй потрібні. Співчуваючи, людина виховує в собі братерську любов, навіть люблячи самого себе, вона любить безпорадну, невпевнену в собі людину, яка потребує допомоги інших. Співчуття передбачає наявність розуміння й ідентифікації з іншим [11, с. 224]. На нашу думку, саме такий прояв любові складає духовну основу діяльності медпрацівника.

У реальності вищезазначені екзистенціали (віра, надія, любов) не існують відокремлено один від одної, вони становлять діалектичну єдність i тому їх потрібно розглядати системно. Названа тріада-це винятково важливі категорії духовного життя людини і суспільства, а отже і духовноморальної культури медпрацівника.

Духовна цінність «совість»-це одна з провідних категорій етики, найбільш складне структурно-функціональне утворення моральнісної самосвідомості особистості та інструмент суспільної оцінки. Совість характеризує здатність особистості здійснювати моральний самоконтроль, самостійно формулювати для себе моральнісні зобов'язання, вимагати від себе їх виконання та здійснювати самооцінку власної діяльності. Совість виявляється як у формі раціонального усвідомлення моральнісного значення здійснюваних дій, так і у формі емоційних переживань (розкаяння, сором тощо). Брак совісті людини в будь-якій галузі діяльності, а особливо у медичній сфері небезпечне появою вседозволеності, нехтуванням правами, свободами й інтересами інших суб'єктів, зокрема пацієнтів.

Важливою духовною цінністю, що є здатністю особистості досягати поставлених цілей в умовах подолання перешкод постає воля. Воля - це феномен регуляції власної діяльності та поведінки, що забезпечує формулювання цілей та концентрацію внутрішніх зусиль на їх досягнення. Людина, яка здійснює вольові дії, протистоїть імпульсивним, миттєвим бажанням; реалізує дисципліну, наполегливість, самоконтроль. За рахунок цього набувається можливість діяти всупереч певним перешкодам чи ігнорувати сильні емоційні переживання. Вольові якості сприяють успішній та ефективній життєдіяльності особистості, тим паче якщо вони підкріплені ентузіазмом. Наприклад, у нашій державі, в умовах сьогодення, потрібно віддати належне працівникам медичної сфери, які при відносно низькій оплаті праці саме завдяки ентузіазму здійснюють належним чином свою професійну діяльність.

У відносинах між лікарем і пацієнтом важливою духовною цінністю є довіра. Ф. Фукуяма у роботі «Довіра» зазначає, що будь-яке суспільне утворення та ступінь його розвитку значною мірою залежить від такої 
духовної цінності як взаємна довіра, яка, в свою чергу, обумовлена існуючою культурою. Довіра - це очікування, яке виникає у членів спільноти, що інші учасники поводитимуться більш чи менш передбачувано, чесно і з увагою до оточуючих, у відповідності з деякими загальними нормами [12, с. 52]. Спільнота, де панує довіра, здатна організувати життєдіяльність людей ефективніше та в більш гнучкому режимі, що набуває, окрім інших, економічних переваг. Довіра між членами спільноти сприяє можливості реалізовувати прогресивні форми суспільного розвитку, з'являтися різним типам соціальних контактів. Відтак, чим більший масштаб довіри, тим ефективнішою $є$ співпраця лікарем і хворим на шляху до спільної мети - здоров'я.

У контексті професійної діяльності медпрацівника однією з визначальних духовних цінностей постає відповідальність. Відповідальність - це специфічна для зрілої особистості форма саморегуляції та самодетермінації, що виражається в усвідомленні себе як причини здійснюваних вчинків та їх наслідків, в розумінні та контролі своєї здатності виступати причиною змін (чи протидією змін) в оточуючому світі та у власному житті. Відповідальність як така актуалізується в межах проблеми уможливлення подальшого існування людства, подолання загрози катастроф планетарного масштабу. Відповідальна діяльність має виходити не з суб'єктивних позицій та переваг, а з формулювання та реалізації спільної фундаментальної вимоги моральнісної відповідальності за всю попередню, сучасну та майбутню людську діяльність. Г. Йонас зазначає, що «імператив, який відповідав би новому типу людської діяльності і був би спрямований на новий тип суб'єкта дії, мав би звучати так: «Чини так, щоб наслідки твоєї діяльності узгоджувалися з продовженням автентичного людського життя на землі», чи, якщо це висловити в негативній формі: «Чини так, щоб наслідки твоєї діяльності не були руйнівними для майбутньої можливості такого життя»...» $[3$, с. 27-28].

Наступна важлива духовна цінність у професійній діяльності медпрацівника є обов’язок, який тлумачиться як суспільна необхідність, що виражена в моральнісних вимогах; де особистість виступає активним носієм моральних зобов’язань та реалізує їх у діяльності. Обов'язок - це сукупність моральних зобов'язань людини перед суспільством. Він виступає як нормативна категорія, що регламентує соціальні обов'язки, які повинен виконувати індивід в силу суспільної необхідності. А. Швейцер справедливо зазначав, що «чим ширша сфера діяльності людини, тим частіше їй доводиться приносити свої почуття в жертву суспільному обов'язку» [13, с. 226]. Проблема обов'язку є надзвичайно актуальною у діяльності, тому відповідні професійні обов'язки працівників медичної сфери відображені у низці міжнародних і вітчизняних нормативних документах. Зокрема, це Міжнародна клятва лікаря, затверджена Генеральною асамблеєю 
Всесвітньої медичної асоціації у 1948 році, Клятва лікаря України у відповідності до Указу Президента України від 15.06.1992 № 349, Етичний кодекс лікаря України, Декларації Всесвітньої медичної асоціації тощо.

Надзвичайно важливою духовною цінністю для медпрацівника $\epsilon$ компетентність. Адже медпрацівник має справу з безцінними здоров’ям і життям людини, його непрофесіоналізм, помилка може дуже «дорогою». На жаль, в українському суспільстві проблема некомпетентності, непрофесійності у конкретній галузі характерна для деяких працівників. Компетентність - це володіння та вміння оперувати достатньою кількістю знань та інформації для вирішення визначеної задачі. Звичайно, не можна бути компетентним в усьому. Знання, коли йде мова про його практичне застосування, може бути ефективним лише у випадку, коли воно спеціалізоване. Тому відмінний спеціаліст вузького сегменту людської діяльності завжди більш поцінований, ніж людина, яка знає про все, але поверхово. Саме цей принцип закладений у підготовці майбутнього лікаря. Значну роль у здобутті компетентності мають духовні цінності, наполегливість та цілеспрямованість як здатності та вміння системно спрямувати власні зусилля на реалізацію визначеної цілі.

\section{Висновки}

Таким чином, можемо констатувати, що віднайдення людиною власної професійної спрямованості пов'язане із визначенням шляху її розвитку, подальших «вітальних» орієнтирів, адже професійна діяльність займає суттєву частину людського життя. Формування професійного медпрацівника з необхідністю має бути спрямоване на розвиток духовно-багатої, ціннісно-орієнтованої особистості, яка є совісною, вольовою, відповідальною, компетентною, наполегливою, цілеспрямованою; послуговується довірою, обов'язком, самовдосконалюється, раціонально використовує власні сутнісні сили, життєвий простір, постійно вдосконалює форми та види своєї діяльності; виховує бережливе ставлення до фізичного, спадково-родового, соціально-психічного та морально-культурного здоров'я, гуманне відношення до людини, повагу до їі особистості, співчуття, доброзичливість, благодійність та милосердя, терплячість, порядність і справедливість.

\section{Список посилань}

1. Американская социология. Перспективы. Проблемы. Методы. [пер. 3 английского: Воронин В.В., Зиньковский Е. В.; ред.: Осипов Г. В. (вступ. ст. )]. Москва: Прогресс, 1972. 392 с.

2. Власенко Ф. (2013). Цінності інформаційного суспільства й розвиток сучасної особистості. Гуманітарний часопис. №4. С. 56-63.

3. Йонас Г.Принцип відповідальності. У пошуках етики для технологічної цивілізації. [пер. з нім]. Київ: Лібра, 2001. 400 с.

4. Ільїн В. В. Фінансова цивілізація. Київ: Книга, 2007. 528 с. 
5. Киселев Г.С. «Тайна прогресса» и возможность истории. Вопросы философии. Москва: Наука, 2009. № 2. С. 3-19.

6. Крилова С.Любов. Філософський енциклопедичний словник. [голова редколегії В. І. Шинкарук]. Київ: Абрис, 2002. С. 348.

7. Левченюк Є. В., Власенко Ф.П. \& Товмаш Д.А. Посткультура в контексті трансгуманізму. Вісник Національної академії керівних кадрів культури і мистецтв, 2019. № 2. С. 166-170. DOI: https://doi. org/10.32461/2226-3209.2.2019.177399

8. Лісовий В. Цінність. Філософський енциклопедичний словник [голова редколегії В. І. Шинкарук]. Київ: Абрис, 2002. С. 707.

9. Підлісний М. М. Проблеми аксіології та шляхи їх вирішення: Монографія. Дніпро: Видавець Біла К. О., 2020. 164 с.

10. Смелзер Н. Д. Социология [под ред. В. А. Ядова]. Москва: Феникс, 1994. $688 \mathrm{c}$

11. Фромм Э. Искусство любить. Исследование природы любви. [перевод Л. Трубицына, А. Ярхо, А. Соловейчик]. СПб.: ИД «Азбукаклассика», 2007. $248 \mathrm{c.}$

12. Фукуяма Ф.Доверие: социальные добродетели и путь к процветанию. [пер. с англ. ]. Москва: ООО «Издательство АСТ»: ЗАО НПП «Ермак», 2004. 730 с.

13. Швейцер А. Благоговение перед жизнью. [пер. с нем., сост. и посл. Гусейнова А.А. и Селезнева М.Г. ]. Москва: Прогресс, 1992. $576 \mathrm{c}$.

References

1. Amerikanskaja sociologija. Perspektivy. Problemy. Metody. (1972). [per. z anglijskogo: Voronin V.V., Zin'kovskij E.V.; red.: Osipov G.V. (vstup. st. )]. Moscow: Progress. 392 p.

2. Vlasenko F. (2013). Cinnosti informacijnogo suspil'stva j rozvytok suchasnoi' osobystosti. Gumanitarnyj chasopys. №4. P. 56-63.

3. Jonas G. (2001). Pryncyp vidpovidal'nosti. U poshukah etyky dlja tehnologichnoi' cyvilizacii'. [per. z nim]. K.: Libra. 400 p.

4. Il'i’n V. V. (2007). Finansova cyvilizacija. Kyiv: Knyga. 528 p.

5. Kiselev G. S. (2009) «Tajna progressa» i vozmozhnost' istorii. Voprosy filosofii. Moscov: Nauka. № 2. P. 3-19.

6. Krilova S. (2002). Ljubov. Filosofs'kij enciklopedichnij slovnik. [golova redkolegiï V.I. Shinkaruk]. Kyiv: Abris. P. 348.

7. Levcheniuk E. V., Vlasenko F.P. \& Tovmash D.A. (2019). Postkul'tura v konteksti transgumanizmu. Visnik Nacional'noï akademiï kerivnih kadriv kul'turi i mistectv. № 2. P. 166-170. DOI: https://doi. org/10.32461/2226-3209.2.2019.177399 
8. Lisovij V. (2002). Cinnist'. Filosofs'kij enciklopedichnij slovnik [golova redkolegiï V.I. Shinkaruk]. Kyiv: Abris. P. 707.

9. Pidlisnij M.M. (2020). Problemi aksiologiï ta shljahi ïh virishennja: Monografija. Dnipro: Vidavec' Bila K. O. 164 p.

10. Smelzer N.D. Sociologija. (1994). [pod red. V.A. Jadova]. Moscow: Feniks. $688 \mathrm{~s}$.

11. Fromm E. (2007). Iskusstvo ljubit'. Issledovanie prirody ljubvi. [perevod L.Trubicyna, A.Jarho, A.Solovejchik]. SPb.: ID «Azbukaklassika». 248 p.

12. Fukujama F. (2004). Doverie: social'nye dobrodeteli i put' k procvetaniju. [per. s angl. ]. Moscow: OOO «Izdatel'stvo AST»: ZAO NPP «Ermak». 730 p.

13. Shvejcer A. (1992). Blagogovenie pered zhizn'ju. [per. s nem., sost. i posl. Gusejnova A. A. i Selezneva M. G. ]. Moscow: Progress. 576 p.

Стаття надійшла до редакцій 03.09.20

(C) Крицький O.В., 2020 